\title{
Protein S100-A4
}

National Cancer Institute

\section{Source}

National Cancer Institute. Protein S100-A4. NCI Thesaurus. Code C102439.

Protein S100-A4 (101 aa, $12 \mathrm{kDa}$ ) is encoded by the human S100A4 gene. This protein is involved in both the positive regulation of signaling and calcium binding. 